\title{
Using the Nominal Group Technique to Explore Key Stakeholders' Perceptions towards Vocational Education Training in Vietnam
}

\author{
Vi Hoang Dang \\ Vocational Education - Namdinh Vocational College - Vietnam \\ University of New England - Australia \\ hdang2@myune.edu.au
}

\begin{abstract}
The Nominal Group Technique (NGT) is a structured process to gather information from a group. The technique was first described in early 1970s and has since become a widely-used standard to facilitate working groups. The NGT is effective for generating large numbers of creative new ideas and for group priority setting. This article reports on a case study carried out in Vietnam on exploring the perceptions of key stakeholders towards the vocational education training (VET) sector where the study will apply the NGT. Therefore, this article has two purposes: (1) describing what NGT is and outlines how to use it; and (2) describing the case study findings by providing an analysis of data generated during a workshop led by the author. The findings of the case study indicated that the Government policy factor or the roles of Government on the VET sector are ranked as the most important force impacting upon the quality of VET programs in Vietnam. Both the established research technique used to collect data and present the findings of the case study have particular significance as they contribute to a major problem which has not been researched seriously in Vietnam in the past as has happened in many other countries. Importantly, the study provides an overview of the Vietnamese VET system which both VET experts in Vietnam and international scholars will be able to understand.
\end{abstract}

Keywords: Nominal group technique, case study, key stakeholders, and vocational education training sector

\section{Introduction}

The Vocational Education Training (VET) sector in Vietnam has a pivotal role in national development and is identified as potentially of equal importance as the university sector. Currently, the VET system has1337 VET providers appearing in all 63 provinces and big cities of Vietnam. It attracts over 1.3 million enrolled students annually and is a priority sector of the Government of Vietnam (GDVT, 2011). In order to enhance the effectiveness and find out the factors impacting the quality of the VET programs in the context of the numbers of secondary students enrolling to VET sector decreasing, the author has undertaken research into the perceptions of students, parents and other key stakeholders. This paper is the third phase of a study to explore the key stakeholders' perceptions towards the VET sector in Vietnam. In the first phase, quantitative survey questionnaire data were statistically analysed using SPSS software version 19 to explore current students' perception about the VET sector that was quantified by seven dimensions, namely: entry requirements, facility and equipment, teacher's ability, recognition of qualification, student career and job potential, quality of curriculum, social values and soft skills. The findings of the first phase indicated that students' positive perceptions of the VET sector included facility and equipment, teachers' ability, quality of curriculum, and social values and soft skills (Dang \& Tanya, 2014). The results also revealed the dimensions of curriculum quality and entry requirements significantly impacted on students' intention to enrol and complete the VET programs.

The second phase was six open-ended interview questions exploring the parental perspectives of the six issues, namely (1) quality and types of VET input; (2) VET teachers' ability; (3) VET facility and equipment; (4) linkages between VET providers and industries; (5) recognition of VET qualifications; and (6) job potential of the VET sector. These questions were designed based on the seven dimensions that represented the VET in the first phase. The results of second phase indicated two main positive and negative themes emerging on five of the issues, the exception being the dimension of the relationship between VET providers and enterprises. The findings revealed that the issue of job potential was evaluated positively by parents' viewpoints. However, it pointed out that there was wastage of trained manpower due to the weak and fragile relationship between VET providers and industries (Dang, 2015). The third phase (this study) used the nominal group technique (NGT) approach to unpack key stakeholders' perceptions towards VET sector to find out the factors impact the quality of VET programs. 
Therefore, this article has two purposes: (1) describing what NGT is and outlines how to use it; and (2) describing the case study findings by providing an analysis of data generated during a workshop led by the author. The key question discussed in the workshop was: What do you think the factors impact the quality of vocational education training programs? At the end of the workshop, the factors that emerged as influencing the quality of VET programs are ranked. Both the established research technique used to collect data and present the findings of the case study have particular significance as they contribute to a major problem which has not been researched seriously in Vietnam in the past as has happened in many other countries. Importantly, the study provides an overview of the Vietnamese VET system which both VET experts in Vietnam and international scholars will be able to understand. The pending next paper of the research will present the triangulation method to triangulate or cross check the results from the initial three phases and provide the final conclusions of the whole project. The results from the surveys, open-ended interview questions, and nominal group technique will be compared to see if similar results emerge. If the conclusions from each of the methods are the same, then validity is established (Mays \& Pope, 2000). Figure 1 describes how data will be triangulated.

\section{Figure 1: Data Triangulation Method}

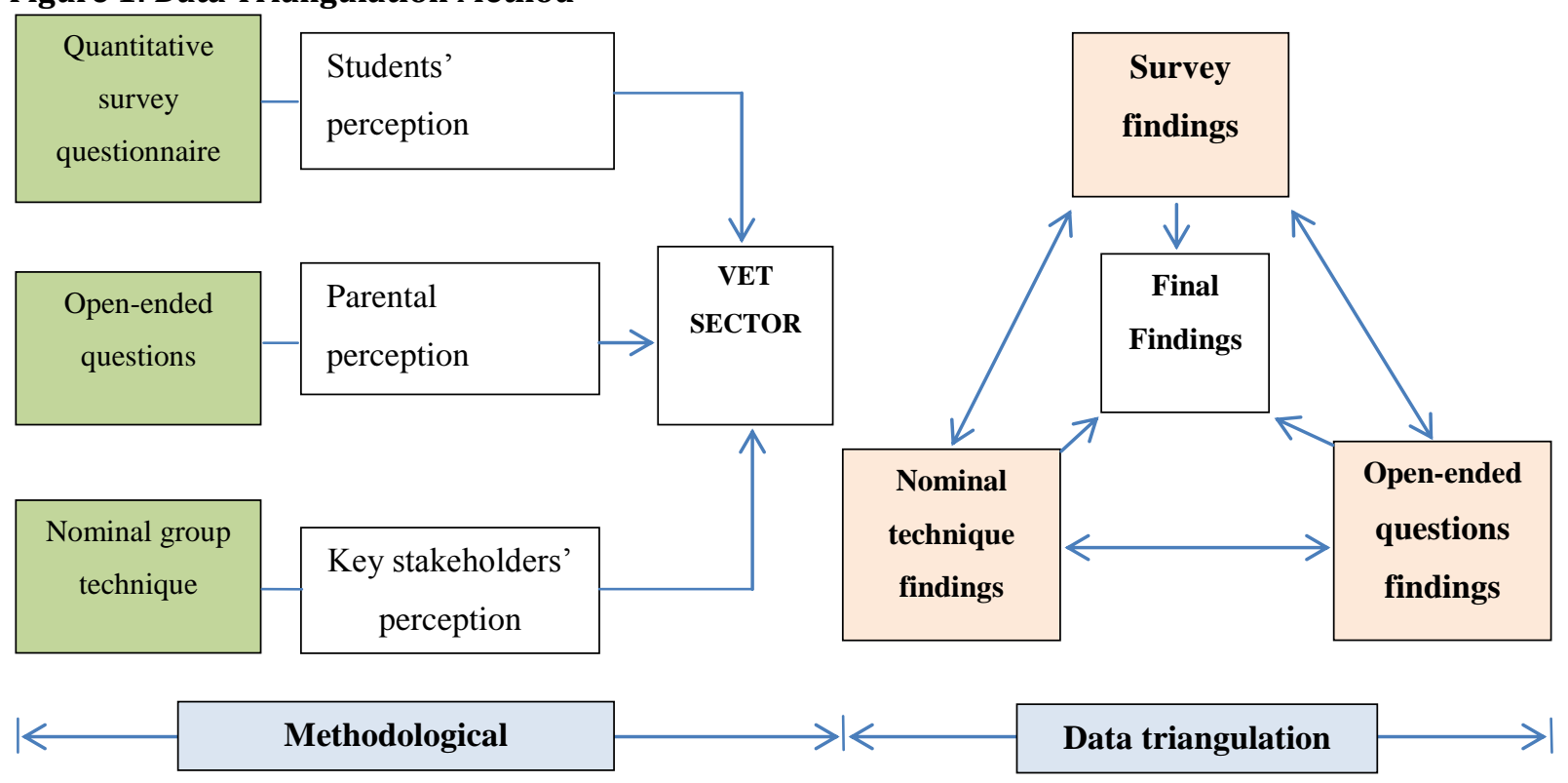

In the third phase of the study, six stakeholders were formally invited based on their roles, the close relationship and a clear understanding on the VET sector. The roles of two policy makers from vocational education training sector and technical education training field will make policies and generate the mechanisms. The roles of principals of secondary schools will help students in advices and guiding career choice in the future. The appearance of manager of industry at the workshop will contribute the ideas on the roles of building up curriculum, evaluations and recruit VET graduates. The VET lecturer will present their understanding and experiences insights the VET sector.

\section{Nominal Group Technique}

Definition: Nominal (meaning in name only) Group Technique (NGT) is a structured variation of a smallgroup discussion to reach consensus (Van de Den \& Delbecq, 1971). Originally, the NGT was introduced by (Van de Den \&Delbecq, 1971) as a tool that helps disadvantaged citizens in community settings. The technique includes two main stages namely focus group discussion, and voting phase. It produces semi quantitative data and its format is used to promote meaningful, interpersonal disclosures among participants by gathering equally weighted responses. NGT evaluation tends to offer valid representation of group views and is well suited to group evaluation activities (Pokorny \& Lyle, 1988). The technique has been widely applied in health, social services, education and government organisations. The contributors taking focus group can be whole cohorts or representative groups of participants.

Development: Since its original development, researchers have modified and adapted the process of the NGT, but basic tenets remain central to the NGT process which comprises of two core stages (1) 
identification the problems by discussion and (2) voting to make decisions quickly. Nominal Group Technique requires direct participant involvement, in a way that is non-hierarchical, and where all participants have an equal voice and all responses to the posed question have equal validity (Harvey \& Holmes 2012). The generation of the responses to the posed question takes place in silence, with no conferring with other participants, nor seeking elucidation or clarification from the researcher. This silent approach to ideas generation enables participants to develop their own thoughts and ideas, without interference or pressure from others, lessening group dynamics that may be unhelpful or undermining to the overall process (McMurray 1994).Valuing of participants individual contributions is enhanced by the fact that through the NGT process, the collection of data and the analysis following ranking of responses, all participants remain anonymous (Steward, 2001), thus allowing all involved to be heard, regardless of position held outside of the participant group

Participants: There has been debate as to what constitutes the optimal size of group for NGT. Van de Ven and Delbecq (1971) suggest that NGT groups should be made up of no more than 5-9 participants, but that large group (9-more than 200) can be accommodated within this process. Whereas, Horton (1980) identified his groups as ranging from 7-10 individuals, whilst Steward (2001) in her work with Occupational Therapy and Physiotherapy students had groups of between 5 and 8. Allen et al. (2004) worked on a number of participants between 9 and 12, noting that this afforded the researcher a group that would be manageable, but that would also allow for the generation of a range of opinions, whilst Harvey and Holmes (2012) suggested that a group of between 6 and 12 would have been ideal. Interestingly, Carney et al. (1996) noted that from their pilot project findings, that a minimum of six participants was required, in order to engender a sense of 'safety' within the group, illustrating this point by outlining that one of the pilot groups in the study had only contained five members and it was perceived that this could be felt as 'mildly threatening'.

NGT versus focus group discussion: A number of authors provide reviews of qualitative research methods (Bellenger, Bernhardt, and Goldstucker, 1976; Bogdan and Taylor, 1975; Higginbotham and Cox, 1979). One of the most insightful of these reviews has been presented by Calder (1977) in which he distinguishes among the exploratory, clinical, and phenomenological dimensions of qualitative research. Although NGT possesses some characteristics of each of these dimensions, it is perhaps closest to what Calder defines as exploratory research. As he points out, a major strength of exploratory methods is the ability to identify major issues or attributes associated with a particular research problem. However, there are several characteristics of standard focus groups that restrict this method to exploratory applications. First, the output of the session is relatively unstructured. Although the session can provide an extensive list of attributes, the process does not facilitate establishing attribute priorities. Second, a small subset of the participants may be outspoken and dominate or intimidate the rest of the group. Third, to minimize this potential domination and to ensure the desired depth of coverage, a highly trained session leader is required. Finally, the necessity to bring participants to a meeting room virtually precludes the use of probability sampling procedures. However, the quota sampling methods usually adopted are entirely consistent with the exploratory nature of the focus group process.

Nominal Group Technique shares with exploratory focus groups the facility for identifying issues relevant to target consumers, and also adds a number of other very useful features. First, in addition to providing an extensive listing of issues or attributes, NGT enables the researcher to identify priorities for each individual session participant. Second, an advantage of NGT is that the structuring and establishing of priorities makes it possible to analyse similarities and differences across multiple NGT sessions. Third, because of the procedural rules established at the outset of the session, the NGT session leader is able to ensure that all participants have an equal voice in the session. Fourth, the authors' experience indicates that the added structure of NGT sessions simplifies the process of training session leaders. In other words, session leadership is somewhat less of an art than appears to be the case with focus group sessions. Despite these advantages, it must be remembered that NGT shares with focus groups the need to assemble participants in the meeting room, and, hence, the necessity to adopt quota sampling procedures.

\section{How to prepare for NGT workshop}

The Meeting Room: Prepare a room large enough to accommodate from five to nine participants. Organize the tables in a U-shape, with a flip chart at the open end of the U. 
Supplies: The U-shaped table set up will need a flip chart; a large felt-tip pen; masking tape; paper, pencil, and 3" x 5" sticky notes for each participant.

Opening Statement: The opening statements have four main parts namely (1) warm welcome to all participants to take part the workshop followed by the purposes of the workshop or the importance of the task, (2) introducing the role of each participant and mention of the importance of each member's contribution, (3) Moderator presents details the guidelines of the NGT process until to all members of the group fully understand, and (4) an indication of how the group's outputs will be used.

The Process of NGT: This section details the NGT process which was applied to the workshop in Vietnam. The process is a combination of the focus group discussion and voting phase that was developed by (Varga-Atkins, 2011) and supported by (James et al., 2004; Alison et al., 2004; Anthony, 2013) studies. It has5phasesnamely: (1) Present key question to the participants; (2) Silent phase; (3) Round Robins phase; (4) Discussion/item clarification phase, and (5) Voting phase. It is noted that all members of group were handed out the instructions of technique one week before the workshop opening so that all participants have time to review the guidelines of the technique. The reason of handing out early instructions of the technique was the majority of the participants who had not used the technique before. Before the first step of discussion, the instructions of the NFGT are explained one more time by author to make sure all participants understand fully and clearly. Table 1 and Figure 2 below describe the instructions of the technique including five steps.

Table 1: Instructions for performing the Nominal Group Technique

\begin{tabular}{|c|c|}
\hline Phases & ctivities \\
\hline Phase 1 & $\begin{array}{l}\text { Present key question on the flip chart and read loudly to the participants for feedback } \\
\text { What factors do you think impact the quality of vocational education training? }\end{array}$ \\
\hline Phase 2 & $\begin{array}{l}\text { Silent phase } \\
\text { Participants will be formed a group of six with a flip chart and pens. } \\
\text { Issue the pink sticky notes to each participant. } \\
\text { Without conferring or group discussion, based on the knowledge and experience of } \\
\text { participants, they write down all factors that they think impact to the quality of vocational } \\
\text { education on the pink sticky notes (one factor per one pink sticky note). }\end{array}$ \\
\hline Phase 3 & $\begin{array}{l}\text { Round-robin phase } \\
\text { In turn, participants stick one pink sticky on the flip chart without comment or discussion } \\
\text { until all ideas or pink sticky notes are exhausted or run out. No comment and discussion in this } \\
\text { phase because of preventing some participants from advocating for their position and } \\
\text { influencing other members in the group. } \\
\text { If one idea (factor) of the participant on the stick note is the same or similar to another's, then } \\
\text { facilitator comments and sticks or groups these together. }\end{array}$ \\
\hline Phase 4 & $\begin{array}{l}\text { Discussion/item clarification to make themes } \\
\text { All members of the group clarify and discuss the unclear factors or items until everything is } \\
\text { understandable } \\
\text { All these items are grouped, edited and named into themes, without discarding any item. } \\
\text { The facilitator list sand letters A, B, C, and so on these themes in order of popularity on the flip } \\
\text { chart. }\end{array}$ \\
\hline Phase 5 & $\begin{array}{l}\text { Voting phase } \\
\text { Based on the list of the themes, participants write down all themes with the letters on the } \\
\text { paper, and rank their top five factors from } 1 \text { to } 5 \text {. } \\
\text { Participants award } 5 \text { points to their top item, } 4 \text { to the second, and so on. } \\
\text { The facilitator collects these papers for data analysis. }\end{array}$ \\
\hline
\end{tabular}


Figure 2: Nominal Group Technique Process

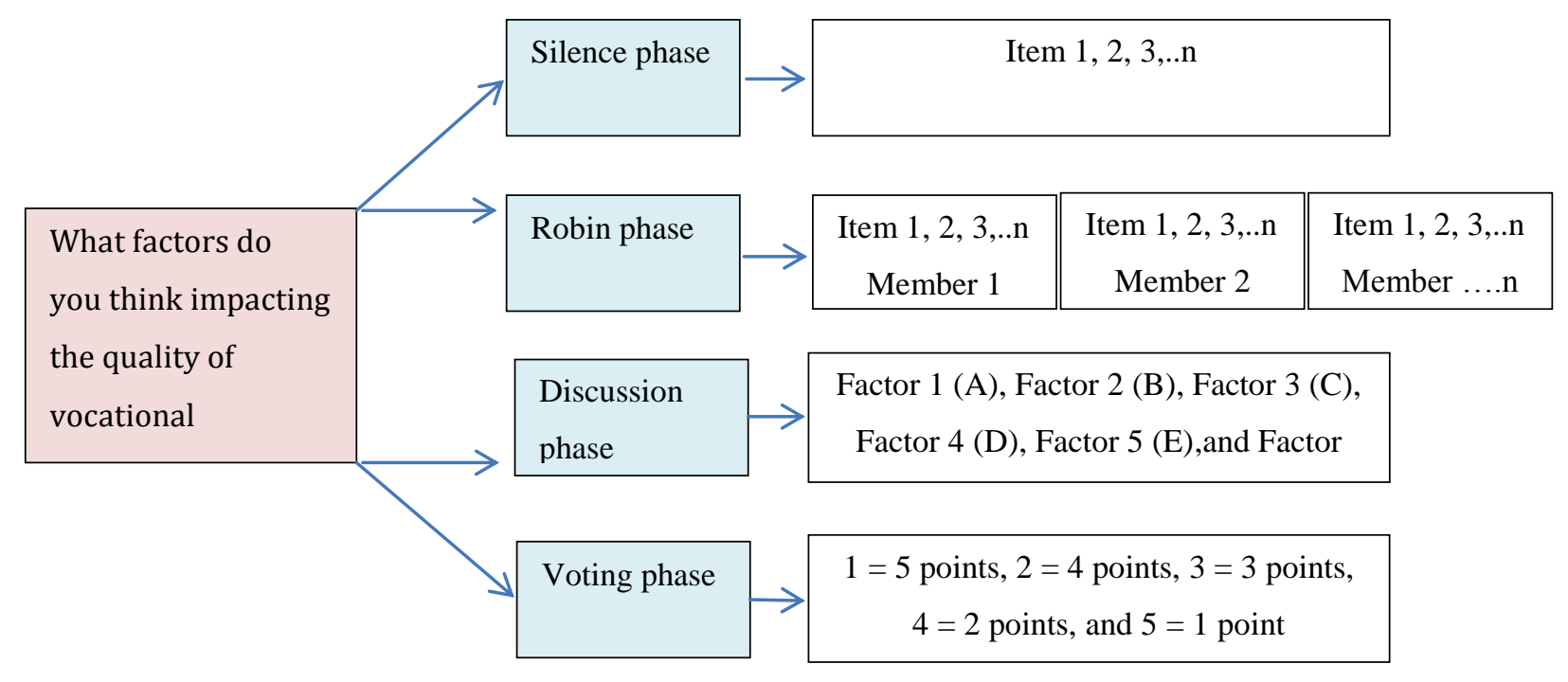

\section{Advantages and disadvantages of NGT}

Advantages: The primary advantage of the NGT over other strategies is the enhanced opportunity for all participants to contribute ideas and to minimize the domination of the process by more confident or outspoken individuals (Vella, Goldfrad, Rowan, Bion \& Black, 2000). Other advantages (Nelson, Jayanthi, Brittain, Epstein \& Bursuck, 2002; de Ruyter, 1996; Brahm \& Kleiner, 1996) include:

- The generation of a greater number of ideas than other group processes.

- The generation of more creative ideas than other group processes.

- The ease of interpreting the results (as ideas are generated, voted on/ranked, and evaluated at the session itself).

- A greater sense of accomplishment for members (as the results are available immediately after the session).

- The minimal resource requirements (a venue, facilitator, whiteboard, paper, sticky notes and pens).

- The comparatively efficient use of time.

Disadvantages: However, it is important to recognise the disadvantages or limitations of nominal groups (de Ruyter 1996; Brahm \& Kleiner 1996). These include:

- The limited number of topics and issues that can be covered (tend to be single-topic sessions).

- The limitation of idea generation to the meeting itself (i.e., no opportunity for participants to think about the issue in depth and generate additional ideas in their own time.

- The need for participants to feel comfortable with, and remain within, a very structured group process.

- The lack of anonymity, which may limit participants' willingness to express their views.

- The necessity for all members to be capable of, and comfortable with, expressing their ideas in writing and then communicating them verbally to the group.

- The time commitment required from participants, and the necessity for them to attend a specific location at a given time, which may limit participant numbers.

- The lack of generalizability of the results to the wider population due to the specific characteristics of the participants (both in terms of who is nominated to attend, and who agrees to participate.

- The limited nature of the data (i.e, in terms of number of respondents) often requires a follow-up survey or other quantitative methodology prior to making final decisions about an issue.

Case study in Vietnam: It is noted that this section provides an overview of VET sector from the perspectives of six key stakeholders who have a clear understanding on, and close relationship with the VET sector. The references in this section were cited and quoted by Vietnamese VET experts and officers from Government who have direct responsibilities, and are in charge of the VET sector. It is acknowledged that a major limitation on the findings is the small sample size but given the exploratory nature of the study, the input of the chosen stakeholders was nevertheless valuable. The views from the six key stakeholders and references from reports by the organizations such as the General Directorate of 
Vocational Training (GDVT), the Asian Development Bank (ADB) and the World Bank are the main official sources to portray the workings of the whole VET sector in this case study. This section provides a series of items to impact upon the quality of VET sector and to point out the weaknesses are exist in the VET system. Six key stakeholders contributed total of 43 individual items and these were generated into 5 themes or factors namely Government policies, Curriculum, The teachers' ability, Facility and equipment, and Perception of society on the VET sector in answering the research question. At the end of the workshop, they voted the factor of Government policies or the role of Government as the most important issue impacting the quality of VET programs. Table 2 shows the results of Nominal group technique.

Facilitator: Vi Hoang Dang

Date: 26 March 2014

Numbers of participants to participate the workshop: 6

Numbers of factors for voting: 5

Topic or question: Please find out what factors do you think impact the quality of vocational education training?

Table 2: Results of Nominal Group Technique

\begin{tabular}{llll}
\hline Factors & $\begin{array}{l}\text { Voted received } \\
\text { 1 is most important = 5 points } \\
\mathbf{5} \text { is least = 1 point }\end{array}$ & $\begin{array}{l}\text { Total } \\
\text { Score } \\
\text { (points) }\end{array}$ & Ranking \\
\hline Government policies on the VET sector & $1+1+1+1+2+3$ & 27 & 1 \\
Curriculum & $1+2+2+3+3+5$ & 20 & 2 \\
The teacher's ability & $1+2+2+4+4+5$ & 18 & 3 \\
Facility and equipment & $2+3+4+4+5+5$ & 13 & 4 \\
Perception of society on the VET sector & $3+3+4+4+5+5$ & 12 & 5 \\
\hline
\end{tabular}

The Government policies and mechanism on the VET sector: Based on the analysis and discussions of six key stakeholders, the factor of Government policies on the VET sector has been ranked as the most important force to impact the quality of VET programs. Stakeholders indicated the policies need to be changed, updated or edited. Regarding the micro level policies on the VET sector such as the policies on the VET system, six stakeholders have pointed out that the complexity of the skilled trained human resource system is the main reason impacting the quality of vocational education training programs. Currently, Vocational Education Training is under the management of the Ministry of Labour Invalid Social Affairs (MOLISA), and Technical Education (TE) belonging the Ministry of Education and Training (MOET) are both responsible for producing the skilled and technical workforce of the country. According to the statistics from MOLISA (2013), at the moment, there were 1337 VET providers, and 500 Technical schools (MOET, 2007). As result, the investment from Government on VET sector appears dilute, and not efficient (Vu, 2015). Thus, six key stakeholders suggested Government should merge the two systems mentioned above into one system to be called Technical and Vocational Education Training system (TVET). This idea is in accordance with the decision of the Prime Minister (630/QD-TTg dated 29-052012) to assign to the concerned ministries responsibility to design the National Qualification Framework (NQF).Such action would result in the merging of the two systems (VET and TE), and help with the recognition of the skills and qualifications of the workforce among the countries in the South East Asian region and other nations in the world. Interestingly, the Vietnam Congress passed the Occupation Education Law dated 27-11-2014 to unify and merge VET and TE to become one Occupation Education system under the direct management by the Prime Minister. In addition, six key stakeholders suggested that the Government should issue more preferential policies to attract and encourage the domestic and international investors to take part in the field of VET. Currently, the policies of the Government just stand at tax breaks for investors (Vocational Law, 2006). As reported by (GDVT, 2011), only 2.4\% of domestic and overseas companies participate in vocational training activities. The companies have established the VET providers for the purpose of training the skilled workforces in order to achieve growth and development of these companies.

In relation with the autonomy policies and mechanism, the participants at the workshop also recommended that Government approve the full autonomy of public VET schools. This would allow VET providers to decide issues such as curriculum, training time, admissions, scientific research, productionbusiness, organization, personnel, and finance. However these decisions must be accountable to the society especially school activities related to the quality of vocational training ( $\mathrm{Vu}, 2015)$. In fact, 
Government just only encourages VET providers autonomously but the detail policies and full instructions for this are not still available. Regarding the policies related to VET students and VET lecturers, six stakeholders also proposed to change, modify and supplement VET policies in order to attract and encourage students to participate the VET programs. VET policy maker who joined the workshop argued that currently the Government has issued the policies to encourage students to participate VET sector by the $50 \%$ reduction of tuition fee. However, the reduction has not been effective to increase enrolments. The solutions to attract secondary students to enrol in VET programs are pointed out by Vice minister of MOLISA (Nguyen, 2014) who suggested that graduated year 9 students who enrol in VET programs receive 100\% reduction of tuition fee. He also reminded that the VET institutions must look for the enterprises for cooperation in vocational education. The ultimate goal is to make the best opportunities for students to find the job. At the workshop, six key stakeholders indicated that, the Government need to promulgated wage framework at each level such as vocational college and vocational secondary. Based on the salary bracket, the enterprises will pay salary to VET graduates suitable with their qualification, knowledge's and experiences. Another disadvantage for VET graduates currently, the Government has no policies and mechanisms to encourage and stimulate employers and enterprises to recruit skilled employees and VET graduates. There are some small and medium businesses employing unskilled workers to work in the company. These businesses only train some employees to meet the needs of the production process in order to make employees to remain with the business for the long term. Presently, businesses are benefiting from the recruitment of skilled workers at no cost including not paying taxes which may be directed to the VET providers (Cao, 2015).

In relation with the policies on the remuneration and salary of the VET lecturers, six key stakeholders have indicated that these policies for VET trainers have many shortcomings. The policies do not encourage or attract potential people to become VET lecturers nor create their loyalty and dedication to the occupation. The requirement to be a VET lecturer necessitates candidates to be a teacher and have technical skills and expertises. However, the wage policies do not show the preferential distinctiveness of being a VET lecturer. In addition VET lecturers do not have their own the salary framework. Their salary is paid according to the salary of the high school teachers (Decree No. 204/2004 / ND-CP, dated 14-122004) and is not equal to the salary of lecturers in the higher education sector. Vice director of the VET research department (Pham, 2015) indicated that the unattractive salary for VET teacher is one of the main reasons for the failure to attract qualified, skilled and experienced people to become VET lecturer. He warned that many skilled and qualified people who work in the VET sector want to move out to other sectors to get higher incomes. In addition, there are no policies to encourage VET teachers to improve their qualifications including the absence of mechanisms for businesses and vocational training institutions to facilitate the VET lecturers for engagement with industries in order to annually improve their knowledge and experiences. According to the Asian Development Bank (ADB, 2014), the present salary level of vocational teachers is comparatively low, and does not encourage or reward improvement of professional and technical skills. These low salary levels make it difficult to recruit skilled technicians or production managers from industry to become VET teachers. There is no incentive program to attract people with extensive industry experience into the teaching profession. Viet Nam does place a high value on teaching and the role of teachers in society, which may explain the absence of policies to improve the status of technical teaching.

One of the problems which six key stakeholders discussed was the policies and mechanisms related to the relationship between VET providers and businesses. According to the Vocational Law (2006), the Vietnamese Government has no specific policies to determine the rights and responsibilities of both organizations involved in this relationship. Enterprises have not seen any advantages in this link whereas VET institutions provide what programs they have available. This relationship does not generate common points between VET providers and enterprises thus leading to VET graduates being disadvantaged because they do not meet the requirements of employers. On the industrial side, enterprises have to invest money and efforts to retrain VET graduates. They are also passive in the process of personnel recruitment (Hoang, 2014). Whereas, VET providers face the difficulties of raising the numbers of student to enrol in VET programs while subjected to the impact of negative social strata (Cao, 2015). For the Government there is wastage of trained manpower. According to the (GDVT, 2011) report, there was $34.27 \%$ of VET graduates did not find a job after 6 months of graduation from VET providers. In other words, the VET graduates do not meet the requirements of industries due to the weak relationship between VET providers and industries. It was the consensus of the key stakeholders at the workshop that the Government has not developed detail policies and mechanisms to identify the rights and 
responsibilities of the two stakeholders in this relationship. The absence of necessary policies is identified as the reason why the VET outputs are not been recognized by society and industry.

Another issue discussed was the implementation of a streaming policy for year 9 and year 12 students. According to GOVT (2011) report and Hoang (2012) the implementation of a streaming policy of year 9 students was failure. "There were only $2 \%$ of year 9 students enrolled to VET providers" (GDVT, 2011). According to the Vice Minister of MOET (Bui, 2013), there are four main explanations for the failure of the streaming policy. Firstly, knowledge about VET programs by individuals, schools and society is generally limited. Secondly, students and their families do not fully understand the ramifications of the academic ability of neither their children nor their economic potential. If they understood these situations, they would see that vocational education may be an attractive way for them to reduce their financial stress and be able to enter the labour market earlier. Thirdly, the labour market information system is poor, not transparency and not regularly updated, whereas the employment potential for VET graduates is positive (Dang, 2015). Lastly, the diversity of the upper secondary school such as public high schools, semi-public high schools and continuing education centres make the implementation of streaming policy difficulty (Bui, 2014). For example, 2014 enrolment in grades 10 at the public upper secondary level in Hanoi city occupied approximately $70 \%$ of the total of 71,278 the year 9 students. This does not include the intakes of enrolment of the semi-public schools and continuous education centres (GDDT Hanoi, 2014). This example reveals that the VET pathway has few year 9 student graduates to enrol.

Curriculum: The second important factor affecting the quality of VET programs comes from the VET curriculum. Three weak points in the design of the VET curriculum were pointed out. Firstly, the VET curriculum currently is not designed based on the output standards or learning outcomes. In other words, the requirements from society especially from industries must be the foundations for the designing of VET curriculum. This statement is in line with the results of the conference title "Development the skilled manpower to meet the needs of society" hosted by MOLISA. The focus was upon the importance of the VET meeting the needs of industries. It is argued that VET providers provide their available programs which are based upon a curriculum not designed to pay attention to the requirements of industries and the realities of manufacture (Cao, 2015). Secondly, the key stakeholders recommended the VET curriculum should be developed to equip students with the theory plus practical and soft skills. In addition, it should be linked to other academic streams to ensure students and VET graduates recognise the need for long life learning. Currently, Vietnam has no national qualification framework (NQF) which identifies the links with other educational pathways. However, the NQF is in the process of designing and is expected to finish at the end of 2015 (Hoang, 2014).

Thirdly, VET curriculum should be designed based on the training of relationship between VET schools and enterprises. The six key stakeholders suggested that the model of Germany's dual vocational training system should be applied to the Vietnamese context. The German VET system provides opportunities for students to be practiced and have the skills to immediately apply their theatrical knowledge in the manufacture environment. Also, students are immersed in a real professional working environment, thus promoting a sense of responsibility and instilling the culture of the company. For students, any mistakes at the enterprise will make a real actual loss, therefore it is lessons for them to self-adjust and improve their skills quickly in the future. On the industrial side, they can control the human workforce in the future and identify the numbers of workers to meet the needs of the company and enterprises can evaluate exactly the quality of each graduated student.

Teacher's ability: One of the factors of the six key stakeholders concerning to impact the quality of VET programs was the ability of VET lecturers. At the workshops, they identified three weak points of VET lecturers that need to be improved. Firstly, basically VET lecturers have a good theatrical knowledge but their practical experiences in industry and teaching methods are limited. This evaluation from six key stakeholders is in line with the $\mathrm{Vu}$ (2013) study results which revealed that only $7.05 \%$ of teachers who teach at vocational college institutions possess a high level of practical skills, and $0.04 \%$ of artisans joining the VET sector were competent in the teaching area. The proportion of VET teachers with high practical skills and artisans at the secondary vocational schools were $5.4 \%$ and $0.32 \%$ respectively, whereas the ratio of VET teachers teaching academic units was a high $63.4 \%$ at vocational college level, and $53.9 \%$ at secondary vocational levels. In addition, there are few institutions training VET teachers (GDVT, 2011). According to a report (2011) from the General Directorate of Vocational Training, vocational teachers are currently sourced from three sectors. The main source of VET teachers is from university. They have the responsibility of the transmission of academic knowledge to students but 
unfortunately their practical skills and teaching methods are limited through inexperience. The second, VET teacher source is from five vocational teacher training institutions (four universities and one at college level). They have studied and are equipped with knowledge in the areas of teaching method, academic knowledge and have practical skills acquired in the industry. Their weakest point is limited or insufficient experience in industry. The last, VET teacher source is from highly skilled workers and artisans. They are strong in the practical area and highly skilled in their particular field by contrast; however, they are inexperienced in teaching method and lack academic knowledge. This finding from the workshops also was in line with the report from (GDVT, 2011, p.47). "Vocational teachers had limitations in occupational skills and competences".

Another weakness of vocational lecturers was the poor response to the updating of information technology skills and the learning of a foreign language. The report from (GDVT, 2011, p.47) documented that "science research, foreign language and applied information technology competences among vocational teachers are still limited. Therefore, their ability to keep themselves updated of new knowledge and technology is yet to be satisfactory". The last issue impacting upon the quality of VET programs identified by the six key stakeholders was the ratio of VET teacher to meet the standard requirements of the General Directorate Vocational Training. According to the report from GDVT (2011, p.45), only $57.8 \%$ of VET teachers met the standards of occupational skill (level 4 per 7 , or equivalent and higher). In regards to the academic skills, the ratio of vocational teachers in vocational colleges was $80.8 \%$, in secondary vocational schools $71.2 \%$, and at the vocational centres $53.5 \%$.

Facility and equipment: The next factor that impact to quality of VET programs was the 21infrastructure and equipment at VET providers. Six key stakeholders listed a series of weaknesses.

- The theoretical studying room and practical workshop have small and insufficient space for practise.

- The place for recreation and sport is not enough.

- The infrastructure such as water system, electricity and toilets to serve at dorm are poor and bad services.

- The equipment for teaching and practising is not enough.

- The equipments for practical lessons are outdated. They always are the old versions compared with the machines and technology of industries. They are not compatible with, nor suitable for the reality of modern manufacturing.

- The materials for practical lessons are not enough, especially with the mechanical occupations such as welding and automobile.

The main reason for the negative evaluations from the key stakeholders on the issue of facility and equipment is the spread and extensive investment by the Government on the public VET providers (Vu, 2015). According to a report from the Institute for Scientific Research Vocational Education (2013), by the end of September 2013, VET network had 1,337 vocational training institutions, including 159 vocational colleges, 305 vocational secondary schools and 873 vocational training centres, increasing 1.5 times more than in 2006. Thus the government cannot have sufficient financial resources to invest in all of the VET providers mentioned above $(\mathrm{Vu}, 2015)$. Besides, the vocational socialization is also facing difficulties due to the lack of specific policies and support mechanisms for investors in the VET sector (Cao, 2015). Interestingly, Vietnamese Government has considered these problems and Vice Prime Minister Vu Duc Dam stressed that the VET sector must be reformed and innovated. He said that "VET sector must look into the facts, review all VET providers and reorganization whole the VET system. Government cannot continue to cover all the ineffective schools."

Perception of society on VET sector: The last factor to impact the quality of VET programs was the perceptions in society of the VET sector. At the meeting, six key stakeholders were in consensus and admitted that the perception of society towards VET pathway was that it had disadvantages in comparison with other academic streams. The most negative view to the VET sector comes from perceptions of parents and students. Vice minister of MOLISA Nguyen (2015) said that "The biggest difficulty for the VET system now is the thinking and perception of parents. Parents always want their children to become the manager. They will not accept if their children working in an industrial environment or becoming blue collar level. Besides, the students do not understand clearly their real capabilities and preferences. They only enrol in VET programs if they have no other studying options". Also at the conference, he indicates the solution to improve parents' perceptions towards VET programs 
was that "Communication is the powerful tool to change the perception of not only students but also parents and other classes in society. Along with consulting the career choice at the high schools and marketing VET programs on the media, we have to make the mechanisms and policies more attractive to encourage young people going to VET programs such as no tuition fee for VET students whereas if students go to university pathway, they must pay huge tuition fee". The following negative view is from the industrial side. The manager of Information Technology Company (one of the members in the panel of the discussion) said that currently, enterprises have priorities or prefer to employ academic graduates, although the jobs require VET graduates. The director explained that the quality of VET inputs (weak academic results at secondary schools) is low. Furthermore, the quality of vocational education training at the VET providers is not highly appreciated. While, annually there over 162,000 bachelors, engineers, even master graduates who do not find a job (MOLISA, 2014).

Another negative view was the knowledge of guidance counsellors at secondary schools on the VET programs is limitation. The principal of lower secondary school (one of the member at the workshop) said that "the understanding of the VET system by guidance counsellors at secondary schools is weak and confused". This statement was in line with the recognition of the Vice director of GDVT (Cao, 2015). He has recognized that the staff and teachers at vocational training institutions and guidance counsellors at secondary schools do not understand fully, nor know clearly, the content of VET programs necessary to advise and inform their students. Moreover, schools want their students to achieve good results at the end of academic year as illustrated by the percentages of students to enrol to year 10 (lower secondary school) and the ratio of high school student who pass the university examination. Teachers at these schools are normally unhappy if their students do not enter the academic pathways. The next negative view is the role of the media on the VET sector. Six key stakeholders pointed out that the media favoured the mainstream educational pathways, whereas the programs of vocational education training have not received adequate attention, commensurate with its role in the industrialization and modernization of the country. In addition, according to Hoang (2014), currently, the educational system of Vietnam is too complicated with unclear definition of the educational levels such as the technical education level, vocational education levels, academic college level and higher educational levels. Also, the connection between other levels of education pathways is limitation, as results it has created the confusion as to the TVET system and does not create confidence in students, parents and employers.

The last negative view from six key stakeholders is the responsibilities of Government towards VET sector. They blamed to the role of Government on opening too many universities in a short period. In this context, VET programs have been disadvantaged in comparison with others academic streams and lack the skilled human resources to serve industry to 2020. According to (MOET, 2014) statistic in the period from 1999 to 2013, 222 universities and colleges were established and up gradated. As result, VET pathway always is the last choice of student to enrol, leading to low recruitment. According to Cao (2015) pointed out that the opening of the both public and private universities has absorbed almost all potential secondary students resulting in few potential students to enrol in the VET programs. As far as the massive establishment of the universities in the short time is concerned, Professor Thuyet (2014) argued that the series of university development in recent times is not reasonable. He said that "In my opinion, to solve the right problem to develop the higher education size, it must be based on at least three parameters. Firstly, it is the demand for manpower in the period of industrialization and modernization of the country. Secondly, it depends on the current capacity of the national economy. Thirdly, it is the ability of the university to meet the requirements of industries and society. In other words, it is the health of the higher education system such as facility and equipment for teaching and learning, and the lecturers' ability". However, the plan of Government on the establishment the higher education system does not rely on these parameters (Nguyen, 2014). According to decision 121/2007/QĐ-TTg of Prime Minister, the development plan of higher education size in 2020 will be 467 universities and colleges not including the institutions in four big cities Hanoi, Ho Chi Minh, Danang and Can Tho. At the moment, the opening too many universities in the short time resulting in three first months of 2014, there were over 162,000 bachelors and masters do not find a job(MOLISA, 2014) whereas lack of high skilled workforce to serve for industries.

\section{Conclusion}

This study presents the history, development, preparation and process of the NGT approach as well as the advantages and disadvantages of the technique in investigating six key stakeholders' perceptions towards VET sector. The use of the nominal group technique enabled six key stakeholders to obtain an extensive 
and varied list of factors that impact the quality of VET. Five most important factors namely Government policies on the VET sector; Curriculum; the teacher's ability; Linking between VET providers and industries; Facility and equipment; Perception of society on VET sector emerged; and Government policies on the VET sector was ranked firstly impacting to the quality of VET programs. The explanation why six key stakeholders voted the factor of Government policies on VET sector as the most important is linked to the definition of perception. The reality changes, the individual's perceptions and attitudes on a phenomenon will be changed (Steven \& Mary, 2003). In other words, Government policies or the roles of Government are key and conclusive factor to make reality changing, as result leading to change the perception. The finding from this study indicates that the current policies of Government on the field of vocational education training such as the policies and mechanisms on the relationship between VET providers and enterprises or the policies on the salary of VET teachers are not strong enough to change the perception of the social strata, especially from students, parents and industries.

The second most important factor: Curriculum impacting the quality of VET programs is linked to the Hoang (2014) statement. "The current TVET curriculum has a big jump of changing towards associated with the capacity standards or skill standards. However, a training program is built well and linked to the needs of the labour market. It just stops in the blueprints". He argued that the quality of VET is related with the activities such as the implementation of teaching and learning process, the assessment, the ability of lecturer, the facilities and equipment, the monitor on the quality of Government and the motivations and attitudes of the learner that they are the key factors. He employed the metaphor of the theatre to explain, that is, a well designed curriculum that is actor poor (lecturers) plus lack of props (facilities and equipment) will not perform well as the script.

Acknowledgement: The author wishes to acknowledge about the project with six key stakeholders, Kay Harman, Daniel Riley that made invaluable contributions to my thinking.

\section{References}

Asian Development Bank, (ADB). (2013). Viet Nam: Vocational and Technical Education Project. Retrieved from http://www.adb.org/documents/viet-nam-vocational-and-technical-educationproject.

Bellenger, D. N., Bernhardt, K. L. \& Goldstucker, J. L. (1976). Qualitative Research in Marketing, Chicago: American Marketing Association.

Bogdan, R. \& Taylor, S. J. (1975). Introduction to Qualitative Research Methods. New York: John Wiley \& Sons, Inc.

Brahm, C. \& Kleiner, B. H. (1996). Advantages and disadvantages of group decision-making approaches. Team Performance Management: An International Journal, 2(1), 30-35.

Bui, V. G. (2014). Họcnghề: Con đườngmònngoằnnghèothiếu an toàn? Retrieved from http://hanoimoi.com.vn/Tin-tuc/Huong-nghiep/653147/hoc-nghe-con-duong-mon-ngoanngheo-thieu-an-toan.

Calder, B. J. (1977). Focus Groups and the Nature of Qualitative Marketing Research. Journal of Marketing Research, 14, 35364.

Carney, O., McIntosh, J. \& Worth, A. (1996). The use of the Nominal Group Technique in research with community nurses. Journal of Advanced Nursing, 23(5), 1024-1029.

Cao, V. S. (2015). 'Trườngnghềkhôngtuyển sinh được do chấtlượnghạnchế'. Retrieved from http://vnexpress.net/tintuc/giao-duc/truong-nghe-khong-tuyen-sinh-duoc-do-chat-luong-hanche 3134427.html.

Dang, H. V. \& Hathaway, T. (2014). Vietnamese Students' Perception and Loyalty towards an Image of Vocational Education and Training. Journal of Education and Vocational Research, 5(4), 228238.

Dang, H. V. (2015). Parental Perspectives towards the Vocational Education Training Sector in Vietnam. Journal of Education and Vocational Research, 6(1), 37-51.

De-Ruyter, K. (1996). Focus versus nominal group interviews: a comparative analysis. Marketing Intelligence \& Planning, 14(6), 44-50.

General Directorate of Vocational Training (GDVT). (2011). Báocáodạnghề 2011. Retrieved from http://www.slideshare.net/tinhanhvy/bo-co-dy-ngh-vit-nam-2011.

Harvey, N. \& Holmes, C. A. (2012). Nominal group technique: An effective method for obtaining group consensus. International Journal of Nursing Practice, 18(2), 188-194. 
Higginbotham, J. B. \& Cox, K. K. (1979). Focus Group Interviews: A Reader. Chicago: American Marketing Association.

Hoang, N. V. (2014). Giáodụcnghềnghiệp: Chưahếtnhứcnhối. Retrieved from http://www.daidoanket.vn/PrintPreview.aspx?ID=95698.

Horton, J. N. (1980). Nominal group technique: A method of decision-making by committee. Anaesthesia, 35(8), 811-814.

McMurray, A. R. (1994). Three Decision-making Aids: Brainstorming, Nominal Group and Delphi Technique. Journal for Nurses in Staff Development, 10(2), 62-65.

Mays, N. \& Pope, C. (2000). Qualitative research in health care: Assessing quality in qualitative research. British Medical Journal, 320(72), 50-52.

Ministry of Labor Invalid Social Affair (MOLISA). (2014). Bản tin cậpnhậtthịtrườnglaođộngViệt Nam, số 2, quí 2 năm2014. 2 Retrieved from http://www.molisa.gov.vn/Images/FileAnPham/fileanpham2014771436556.pdf.

Ministry of Education and Training (MOET). (2013). Thốngkếgiáodụcnăm 2013. Retrieved from http://www.moet.gov.vn/?page=11.11\&view=5251.

Nelson, J. S., Jayanthi, M., Brittain, C. S., Epstein, M. H. \& Bursuck, W. D. (2002). Using the Nominal Group Technique for homework communication decisions. Remedial and Special Education, 23(6), 379-386.

Nguyen, M. T. ( 2014). 72000 ngườithấtnghiệpvà tráchnhiệmcủangànhgiáodục . Retrieved from http://www.giaoducvietnam.vn/Giao-duc-24h/72000-nguoi-that-nghiep-va-trach-nhiem-cuanganh-giao-duc-post144781.gd

Nguyen, N. P. (2014). Chínhsáchchongườihọcnghềphảitốthơn! Retrieved from http://cdn.ptit.edu.vn/tintuc-su kien/chinh-sach-cho-ng\%C6\%B0\%E1\%BB\%9Di-h\%E1\%BB\%8Dc-ngh\%E1\%BB\%81ph\%E1\%BA\%A3i-t\%E1\%BB\%91t-h\%C6\%A1n/

Nguyen, T. D. (2015). Thayđổinhậnthứcchọnnghềchocảhọc sinh vàphụhuynh. Retrieved from http://www.thanhnien.com.vn/giao-duc/thay-doi-nhan-thuc-chon-nghe-cho-ca-hoc-sinh-vaphu-huynh-527318.html.

Pham, X. T. (2015). Pháttriểnđộingũgiáoviêndạynghềgópphầnđổimớicănbản, toàndiệnnềngiáodục Việt Nam. Retrieved from http://tuyengiao.vn/Home/MagazineContent?ID=1394.

Pokorny, L. \& Lyle, K. (1988). Introducing a modified nominal group technique for issue identification. Evaluation Practice, 9(2), 40-43.

So GiaoDuc Dao Tao Hanoi (GDDT Hanoi). (2014). HàNội: 71,278 HS đăngkýdựthivàolớp 10. Retrieved from http://news.vn/giaoduc/tuyen-sinh/329872-Ha-Noi-71.278-HS-dang-ky-du-thi-vao-lop10.html.

Steven, L. M. C. \& Mary, A. Y. V. G. (2003). Organizational behaviour. Toronto: McGraw-Hill Ryerson.

Steward, B. (2001). Using Nominal Group Technique to Explore Competence in Occupational Therapy and Physiotherapy Students during First-Year Placements. British Journal of Occupational Therapy, 64(6), 298-304.

Van de Ven, A. \& Delbecq, A. L. (1971). Nominal versus Interacting Group Processes for Committee Decision-Making Effectiveness. Academy of Management Journal, 14 (2), 203 -212.

Varga-Atkins, T., Bunyan, N., McIsaac, J. \& Fewtrell, J. (2011). The Nominal Group Technique: a practical guide for facilitators. Written for the ELESIG Small Grants Scheme, University of Liverpool, October, Version 1.0.

Vella, K., Goldfrad, C., Rowan, K., Bion, J. \& Black, N. (2000). Use of consensus development to establish national research priorities in critical care. British Medical Journal, 320(7240), 976-980.

$\mathrm{Vu}$, D. D. (2015). Đổimóritoàndiệndạynghêđđảmbảoan sinh xãhội. Retrieved from http://tcdn.gov.vn/AIAdmin/News/View/tabid/66/newsid/5941/seo/Pho-Thu-tuong-VuDuc-Dam-Doi-moi-toan-dien-day-nghe-dam-bao-an-sinh-xa-hoi/Default.aspx.

Vu, X. H. (2013). Thựctrạngthihànhphápluậtdạynghềvàkiếnnghịcácnội dung cầnsửađổi, bổ sung vào luậtdạnghề. Retrieved from http://khcn.molisa.gov.vn/doc/Tom\%20tat\%20De\%20tai.pdf. 